\title{
Studies on Oxalic Acid Metabolism in Begonia Plant
}

\author{
by Kimiko SASAKI*
}

Received November 12, 1962

Oxalic acid found in higher plants is considered to be formed from acetic acid via glycolic and glyoxylic acids as in the case in certain fungi ${ }^{1)}$, while it is produced in Aspergillus niger from oxalacetic acid by oxalacetic hydrase ${ }^{2,31}$. Oxalic acid has been considered to be a by-product of plant metabolism which, when once formed, is not readily used up. In this respect the findings of Franke et al. . $^{4}$ is worthy of note that a moss, Hylocomium triquetrum and leaves of several plants, such as sorrel, rhubarb, clover, and spinach, contain an oxalodehydrogenase. The enzyme from the moss differs from that of higher plants in the stability to heat and in $\mathrm{pH}$ and tem. perature optima. The enzyme is inhibited by nitrate but not by cyanide, sulfide, or arsenite. The enzyme from a moss, Bryoles appears to be a flavin mononucleotide enzyme $^{5)}$. Another type of oxalate oxidation has been demonstrated by Blom and Niekerk $^{6)}$, who showed that the cell suspension of mosses brought about the oxidation of oxalic acid to hydrogen peroxide and carbon dioxide and that this reaction is inhibited either by cyanide or by lack of oxygen. However, as purified enzyme preparation was used, the inhibition by cyanide cannot be a proof for the difference of their enzyme from that of Franke et al. On the other hand, Jakoby, Ohmura and Hayaishi $^{7}$ ) found that extracts of an oxalate-grown bacterium catalyzed an anaerobic decarboxylation of oxalic acid to formic acid and carbon dioxide, which was dependent upon the presence of substrate amounts of adenosine triphosphate and catalytic quantities of acetate, coenzyme A, thiamine pyrophosphate, and magnesium ions. The enzyme from Cellyvia veltipes produced formic acid and carbon dioxide in the presence of catalytic amounts of oxygen ${ }^{8)}$. Thus, various types of enzyme were found to exist in oxalic acid metabolism. In green plants hydrogen peroxide is usually produced during oxalate oxidation ${ }^{5,9,10)}$.

In higher plants the physiological role of oxalate metabolism is not clarified despite the wide occurrence of this acid in plants. The possible involvement of glyoxylate in oxalate metabolism is of particular interest in view of the earlier suggestion ${ }^{1,12}$ that the growth on oxalate medium may proceed through primary oxidation of oxalate to carbon dioxide and subsequent fixation of the latter by mechanisms similar to those operated in autotrophic organisms ${ }^{13)}$. The presence of such mechanisms would demand the existence of carboxydismutase, in oxalate-grown cells ${ }^{14}$ an enzyme catalyzing the carboxylation of ribose 1,5-diphosphate. Pseudomonas oxalaticus cells grown on oxalate actually contain non-detectable quantities of carboxydismutase ${ }^{15}$. Jakoby and Blat ${ }^{16)}$ suggested that some compounds differing from oxalate serves as both carbon and energy sources although formate is formed by anaerobic decarboxylation of oxalate. However, little is known about whether the details of the biosynthetic routes from oxalate to cell materials are similar to those operating in cells grown on glycolate or glycine, or they are unlike those occurring in cells growing on C-1 compounds. In higher plants, it also appears that the routes of oxalate assimilation are similar to those found in the oxalate-grown autotrophic cells.

* Department of Botany. Faculty of Science, Hokkaido University, Sapporo, Japan 
Begonia plants contain a large amount of free oxalic acid and oxalic acid oxidizing enzyme. Thus, the plant appears to be a material suitable for the studies of the above mentioned problems. In this paper, the results of the studies on some properties of oxalic acid oxidase of Begonia semperflorens are reported.

\section{Material and Methods*}

Material: Begonia semperflorens plants grown in standard green house were used as the material.

Preparation of cell-free enzyme: Fifty grams of leaves were washed thoroughly with deionized water and macerated in a mortar with $1 / 5$ volumes of ice-cooled homogenizing medium, such as deionized water, $0.01 \mathrm{M}$ phosphate buffer ( $\mathrm{pH} 5.5$ or 7.2), and $0.01 \mathrm{M}$ phosphate buffer ( $\mathrm{pH} 7.2$ ) plus $05 \mathrm{M}$ sucrose. The resultant homogenate was filtered through 2 layers of cheesecloth. After centrifugation at $400 \times g$ for 3 to 5 minutes, the filtrate was centrifuged at 1,000 to $1,200,8,000,10,000$ to 14,000 , and $24,000 \times g$, successively. Each sediment was washed twice with the homogenizing medium. The washed materials were further dispersed in a glass homogenizer with the homogenizing medium and used directly or after storage at $0^{\circ}$. Sometimes, $10 \mathrm{~g}$ of flowering tissues were treated by the same procedure.

Preparation of sonicate of particulate fractions: The 1,000 to $1,200 \times g$ sediments, included mainly whole chloroplasts, and $8,000 \times g$ sediments, including broken chloroplasts; each of the fractions was submitted to oscillation in a 9-kc, Kubota vibrator for 10 minutes, and then centrifuged at 10,000 and $13,000 \times g$ for 10 minutes to separate the extract from the particles.

Preparation of lipase extract of particulate fractions: The chloroplast fractions were treated with $5 \mathrm{mg}$ of lipase (Tokyo Kasei Chemical Co.) in $0.01 \mathrm{M}$ phosphate buffer, $\mathrm{pH} 7.2$, per $100 \mathrm{mg}$ of protein, at $30^{\circ}$ for 20 minutes or at room temperature for 2 hours. Thereafter, a clear extract was obtained by centrifugation at $10.000 \times g$ for 10 minutes and the resultant residue was washed with deionized water.

Preparation of DOC and digitonin extracts of particulate fraction: The chloroplast fractions were treated with either $0.5 \%$ DOC or $1 \%$ digitonin each in $0.01 \mathrm{M}$ phosphate buffer, $\mathrm{pH} 7.2$, at $30^{\circ}$ for 2 hours or at $0^{\circ}$ overnight, and the clear extract was separated by centrifugation at $10,000 \times g$ for 20 minutes.

Assay of activity of enzyme: The activity of oxalic acid oxidase was measured by means of a Warburg respirometer at $30^{\circ}$. Reaction medium was made up of sufficient amounts of enzyme materials, $0.5 \mathrm{ml}$ of $0.5 \mathrm{M}$ phosphate or acetate buffer, and 0.2 $\mathrm{m} l$ of $0.2 \mathrm{M}$ potassium oxalate in a total volume of $2.0 \mathrm{ml}$. Controls were run without oxalate. As intact materials, $100 \mathrm{mg}$ of fresh weight of tissue slices were used. The reaction times were 60 minutes with slice and 10 to 20 minutes with cell-free enzyme preparations. In several cases, each of FMN, FAD, RF, $\mathrm{NaNO}_{3}, \mathrm{NaNO}$, and $\left(\mathrm{NH}_{4}\right)_{2} \mathrm{SO}_{4}$ was added to the above listed medium. The activity was expressed as $\mathrm{QO}_{2}$.

Estimation of oxalic acid: An aliquot of each cell-free extract of water-homogenate of various tissues was chromatographed on filter paper (Toyo's No. 2) with $n$-butyl alcohol-formic acid-water $(4: 1.5: 1)$ combining a spray of $0.2 \%$ bromocresol blue solution, and the color intensity of the oxalic acid spot was determined colorimetrically.

Determination of protein in crude enzyme solution: The determination was made

* Following abbreviations are used: Adenosine triphosphate, ATP; Flavin mononucleotide, FMN; Flavin adenine dinucleotide, FAD; Riboflavin, RF; Deoxycholate, DOC. 
by the Neilson method $^{17)}$.

\section{Results}

Localization of oxalic acid and oxalic acid oxidase: As shown in Table 1, oxalic acid and oxalic acid oxidase were found in various tissues. Oxalic acid was largely present in the homogenates of leaves and petals and the oxidase in stigma and stamen.

Table 1. Presence of oxalic acid and oxalic acid oxidase in homogenates of various tissues.

Assay condition of oxalic acid oxidase: 1-4 mg of dry weight of tissue homogenate, $0.025 \mathrm{M}$ phosphate buffer (final concentration), $\mathrm{pH} 5.5 ; 0.02 \mathrm{M}$ potassium oxalate (final centration), $2.0 \mathrm{ml} ; 30^{\circ} ; 20$ minutes.

\begin{tabular}{ll|c|c|c}
\hline \multicolumn{2}{c|}{ Tissue } & $\begin{array}{c}\mathrm{pH} \\
\text { of } \\
\text { homogenate }\end{array}$ & $\begin{array}{c}\text { Presence } \\
\text { of } \\
\text { oxalic acid* }\end{array}$ & $\begin{array}{c}\text { Activity } \\
\text { of } \\
\text { oxalic acid } \\
\text { oxidase }\left(\mathrm{Qo}_{2}\right)\end{array}$ \\
\hline \multirow{2}{*}{ Male flower } & Stamen & 3.4 & + & 26 \\
\multirow{2}{*}{ Female flower } & Petal & 1.8 & ++ & 5 \\
& Ovary & 5.2 & + & 7 \\
\multirow{2}{*}{ Leaves } & Stigma & 3.2 & + & 14 \\
\hline
\end{tabular}

*,,++++++ Degree of amounts of free oxalic acid present in deionized waterhomogenate. Tissue materials were harvested during the flowering stage and homogenized with same volume of deionized water.

The various fractions separated from leaf homogenates by the differential centrifugation were tested for oxalic acid oxidase. At the same time, the activity of catechol oxidizing enzyme was assayed as an example of enzyme easily solubilized from the particulate fractions of leaf homogenate ${ }^{18)}$. As seen in Table 2, the washed whole chloroplast fraction obtained from homogenates with deionized water or $0.5 \mathrm{M}$ sucrose showed the strongest activity for oxalic acid oxidase compared with other fractions. The activity of oxalic acid oxidase appeared to be elevated by the homogenization with deionized water compared with $0.5 \mathrm{M}$ sucrose. On the other hand, catechol oxidizing enzyme was most abundant in the largest particles of $0.5 \mathrm{M}$ sucrosehomogenate or in the $24,000 \times g$-supernatant fluid of deionized water-homogenate. In the $0.01 \mathrm{M}$ phosphate buffer-homogenate, both the enzymes were largely localized in the fractions consisting of smaller fragments of chloroplasts.

Effect of sonic vibration: Chloroplasts and chloroplast fragments were subjected to sonic vibration. The treatment resulted in the partial disruption of the particles to small fragments and the partial solubilization of oxalic acid oxidase. The sum activity of the extract and residue was higher than the activity of the original chloroplasts and their fragments as a result of the disruption to smaller fragments (Table 3, Exp. 2).

Effect of lipase: The treatment with lipase of chloroplasts and their fragments 
Table 2. Localization of oxalic acid oxidase in several fractions of leaf homogenate. Assay condition was the same as in Table 1 excepting the use of $100 \mathrm{mg}$ of fresh weight of leaf slices.

\begin{tabular}{|c|c|c|c|c|}
\hline \multirow{3}{*}{ Fraction } & \multicolumn{4}{|c|}{$\mathrm{Qo}_{2}$} \\
\hline & \multicolumn{2}{|c|}{$1 *$} & \multicolumn{2}{|c|}{$2 * *$} \\
\hline & Oxalic acid & Catechol & Oxalic acid & Catechol \\
\hline Slice & 4 & 148 & & \\
\hline Homogenate & 1 & 40 & & \\
\hline Sediment-I $(1,500 \times g)$ & 81 & 25 & 13 & 225 \\
\hline Sediment-II $(8,000 \times g)$ & 28 & 15 & 9 & 95 \\
\hline Sediment-III $(14,000 \times g)$ & 48 & 21 & 5 & 21 \\
\hline Sediment-IV $(24,000 \times g)$ & 46 & 70 & 5 & 3 \\
\hline $\begin{array}{l}\text { Supernatant }(24,000 \times g) \\
\text { Precipitate with } 100 \% \text { sat. } \\
\quad\left(\mathrm{NH}_{4}\right)_{2} \mathrm{SO}_{4} \text { obtained from } \\
\text { "S Supernatant }(24,000 \times g) \text { " }\end{array}$ & $\begin{array}{l} \pm \\
7\end{array}$ & $\begin{array}{l}220 \\
137\end{array}$ & $\begin{array}{l} \pm \\
9\end{array}$ & $\begin{array}{r}17 \\
7\end{array}$ \\
\hline
\end{tabular}

$*$ and $* *$, deionized water (Experiment-1*) and $0.5 \mathrm{M}$ sucrose solution (Experiment-2**) were used as homogenizing and suspending media, respectively.

Table 3. Effect of sonic oscillation of chloroplast suspension on extraction of oxalic acid oxidase. Assay condition was the same as in Table 1.

\begin{tabular}{|c|c|c|c|c|}
\hline $\begin{array}{c}\text { Exp. } \\
\text { No. }\end{array}$ & Fraction & $\mathrm{Qo}_{2}$ & $\begin{array}{l}\text { Dry } \\
\text { weight } \\
\text { (total } \\
\text { mg) }\end{array}$ & $\begin{array}{c}\mathrm{O}_{2} \text { uptake } \\
\left(\mathrm{Qo}_{2} \times \text { total }\right. \\
\text { mg of } \\
\text { dry weight })\end{array}$ \\
\hline \multirow[t]{6}{*}{1} & Sediment.I $(1,500 \times g)$ & & & \\
\hline & Original & 81 & 38.0 & 3078 \\
\hline & Sonicate & 37 & & \\
\hline & Fraction-I $(10,000 \times g$-ppt. $)$ & 37 & 12.2 & 456 \\
\hline & Fraction-II $(24,000 \times g$-ppt. $)$ & 33 & 15.0 & 495 \\
\hline & Fraction-III (24,000 $\times g$-supernatant.) & 28 & $11.0 *$ & 308 \\
\hline \multirow[t]{6}{*}{2} & Sediment-II $(8,000 \times g)$ & & & \\
\hline & Original & 10 & 36.0 & 360 \\
\hline & Sonicate & & & \\
\hline & Fraction-I $(10,000 \times g$-ppt. $)$ & 123 & 14.3 & 1759 \\
\hline & Fraction-II $(24,000 \times g$-ppt. $)$ & 23 & 14.3 & 329 \\
\hline & Fraction-III $(24,000 \times g$-supernatant. $)$ & 1080 & $0.6^{*}$ & 648 \\
\hline
\end{tabular}

* mg of protein. 
brought about the partial solubilization of oxalic acid oxidase and catechol enzyme (Table 4). The sum of activity of oxalic acid oxidase in the extract and in the residue of lipase-treated material was larger than that of non-treated sample. Most of oxalic acid oxidase was precipitated with $100 \%$ saturated $\left(\mathrm{NH}_{4}\right)_{2} \mathrm{SO}_{4}$ from the lipase-treated extract.

Table 4. Effect of lipase on extraction of oxalic acid oxidase from chloroplast fraction.

Deionized water was used as a suspending medium of "Fraction-I $(1,500 \times g)$ ". Assay condition was the same as in Table 1.

\begin{tabular}{|c|c|c|c|c|}
\hline \multirow[b]{2}{*}{ Fraction } & \multirow[b]{2}{*}{$\mathrm{Qo}_{2}$} & \multicolumn{2}{|c|}{ Protein } & \multirow{2}{*}{$\begin{array}{c}\mathrm{O}_{2} \text { uptake } \\
\left(\mathrm{QO}_{2} \times \text { total }\right. \\
\mathrm{mg} \text { of } \\
\text { protein })\end{array}$} \\
\hline & & $\begin{array}{c}\text { (Total } \\
\text { mg) }\end{array}$ & $\begin{array}{c}\text { Degree } \\
\text { of extrac- } \\
\text { tion, } \%\end{array}$ & \\
\hline $\mathrm{H}_{2} \mathrm{O}$ suspension & 24 & $133.0 * *$ & & 3200 \\
\hline Sonic extract, $100 \%$ sat. $\left(\mathrm{N}^{\prime} \mathrm{H}_{4}\right)_{2} \mathrm{SO}_{4}-\mathrm{ppt}$ & 78 & 32.2 & 24.2 & 2500 \\
\hline Lipase extract, $100 \%$ sat. $\left(\mathrm{NH}_{4}\right)_{2} \mathrm{SO}_{4}$-ppt & 620 & 3.7 & 2.8 & 2300 \\
\hline Lipase residue, $\mathrm{H}_{2} \mathrm{O}$ extract- $1^{*}$ & 610 & 4.0 & 3.0 & 2430 \\
\hline Lipase residue, $\mathrm{H}_{2} \mathrm{O}$ extract. $2^{*}$ & 181 & 7.7 & 5.8 & 1290 \\
\hline Lipase residue, $\mathrm{H}_{2} \mathrm{O}$ residue* & 52 & 62.0 & & 3220 \\
\hline
\end{tabular}

* Extracts obtained by successive washing of "Lipase residue" with deionized water and the non-extractable residue.

** Dry weights were measured.

Table 5. Effects of deoxycholate and digitonin on extraction of oxalic acid oxidase from chloroplasts.

\begin{tabular}{|c|c|c|c|c|c|c|}
\hline \multirow{3}{*}{\multicolumn{2}{|c|}{ Fraction }} & \multicolumn{2}{|c|}{$\mathrm{QO}_{2}$} & \multirow{3}{*}{$\begin{array}{l}\text { Dry } \\
\text { weight } \\
\text { (Total } \\
\text { mg) }\end{array}$} & \multirow{2}{*}{\multicolumn{2}{|c|}{$\begin{array}{c}\mathrm{O}_{2} \text { uptake } \\
\left(\mathrm{QO}_{2} \times \text { total } \mathrm{mg}\right. \\
\text { of dry weight })\end{array}$}} \\
\hline & & \multirow{2}{*}{ Oxalate } & \multirow{2}{*}{ Catechol } & & & \\
\hline & & & & & Oxalate & Catechol \\
\hline \multicolumn{7}{|c|}{$1,500 \times g$-sediments } \\
\hline & $0.25 \mathrm{M}$ sucrose suspension & 12 & 4 & 64.0 & 768 & 256 \\
\hline & extract & 93 & 22 & $4.7^{*}$ & 437 & 103 \\
\hline & residue & 23 & & 50.0 & 1150 & \\
\hline \multirow[t]{2}{*}{3.} & Digitonin extract & 39 & & $0.8^{*}$ & 31 & \\
\hline & Digitonin residue & 34 & & 58.5 & 1989 & \\
\hline & extract & $\pm * *$ & 1350 & $1.2^{*}$ & $\pm^{*}$ & 680 \\
\hline & residue & 8 & & 63.8 & 510 & \\
\hline
\end{tabular}

* In the experiments with extracts, protein was measured.

$* * \pm$, Activity was very weak 
Table 6. Fractionation of oxalic acid oxidase with ammonium sulfate.

\begin{tabular}{|c|c|c|c|}
\hline \multirow{2}{*}{$\begin{array}{c}\text { Exp. } \\
\text { No. }\end{array}$} & \multirow{2}{*}{ Fraction } & \multicolumn{2}{|c|}{$\mathrm{Qo}_{2}$} \\
\hline & & Oxalate & Catechol \\
\hline 1 & $\begin{aligned} & 24,000 \times \text { g-supernatant } \\
& 5 \% \text { sat. }\left(\mathrm{NH}_{4}\right)_{2} \mathrm{SO}_{4} \text {-ppt. } \\
& 10 \% \text { sat. }\left(\mathrm{NH}_{4}\right)_{2} \mathrm{SO}_{4} \text {-ppt. } \\
& 20 \% \text { sat. }\left(\mathrm{NH}_{4}\right)_{2} \mathrm{SO}_{4} \text {-ppt. } \\
& 50 \% \text { sat. }\left(\mathrm{NH}_{4}\right)_{2} \mathrm{SO}_{4} \text {-ppt. } \\
& 100 \% \text { sat. }\left(\mathrm{NH}_{4}\right)_{2} \mathrm{SO}_{4} \text {-ppt. }\end{aligned}$ & $\begin{array}{l}+ \\
19 \\
+ \\
+ \\
+\end{array}$ & $\begin{array}{r}81 \\
39 \\
-137 \\
135\end{array}$ \\
\hline 2 & $\begin{array}{l}\text { 1, } 500 \times g \text {-sediment } \\
\text { Lipase extract } \\
\text { Lipase extract, } 100 \% \text { sat. }\left(\mathrm{NH}_{4}\right)_{2} \mathrm{SO}_{4} \text {-ppt-1* } \\
\text { Lipase extract, } 100 \% \text { sat. }\left(\mathrm{NH}_{4}\right)_{2} \mathrm{SO}_{4} \text {-ppt-2* } \\
\mathrm{H}_{2} \mathrm{O} \text { extract } * * \\
\mathrm{H}_{2} \mathrm{O} \text { extract, } 100 \% \text { sat. }\left(\mathrm{NH}_{4}\right)_{2} \mathrm{SO}_{4} \text {-ppt-1* } \\
\mathrm{H}_{2} \mathrm{O} \text { extract, } 100 \% \text { sat. }\left(\mathrm{NH}_{4}\right)_{2} \mathrm{SO}_{4} \text {-ppt-2* }\end{array}$ & $\begin{array}{r}20 \\
166 \\
2 \\
170 \\
79 \\
0 \\
368\end{array}$ & $\begin{array}{r}950 \\
0 \\
945 \\
\\
0 \\
170\end{array}$ \\
\hline 3 & $\begin{array}{l}\text { 8, } 000 \times g \text {-sediment } \\
\text { Lipase and } \mathrm{H}_{2} \mathrm{O} \text { extract, } 100 \% \text { sat. }\left(\mathrm{NH}_{4}\right)_{2} \mathrm{SO}_{4} \text {-ppt-1* } \\
\text { Lipase and } \mathrm{H}_{2} \mathrm{O} \text { extract, } 100 \% \text { sat. }\left(\mathrm{NH}_{4}\right)_{2} \mathrm{SO}_{4} \text {-ppt-2* } \\
\text { Lipase and } \mathrm{H}_{2} \mathrm{O} \text { extract }\end{array}$ & $\begin{array}{r}16 \\
150 \\
25 \\
298\end{array}$ & $\begin{array}{r}1000 \\
32 \\
525\end{array}$ \\
\hline
\end{tabular}

* Precipitate- 2 was sediment formed by centrifugation at $10,000 \times g$ for 10 minutes from $100 \%$ salurated $\left(\mathrm{NH}_{4}\right)_{2} \mathrm{SO}_{4}$ solution, while Precipitate-1 came on surface of the solution at $10,000 \times g$ and was sedimented at $13,000 \times g$ for 10 minutes.

** Deionized water.extract obtained from the residue separated fiom "Lipase extract".

Table 7. Fractionation of oxalic acid oxidase with acetone.

\begin{tabular}{|c|c|c|c|c|c|c|}
\hline \multirow{3}{*}{$\begin{array}{l}\text { Exp. } \\
\text { No. }\end{array}$} & \multirow{3}{*}{ Fraction } & \multicolumn{2}{|c|}{$\mathrm{QO}_{2}$} & \multicolumn{3}{|c|}{ Total } \\
\hline & & \multirow{2}{*}{$\begin{array}{l}\text { Oxalic } \\
\text { acid }\end{array}$} & \multirow{2}{*}{$\begin{array}{l}\text { Cate- } \\
\text { chol }\end{array}$} & \multirow{2}{*}{$\begin{array}{c}\text { Protein } \\
(\mathrm{mg})\end{array}$} & \multicolumn{2}{|c|}{$\begin{array}{c}\mathrm{O}_{2} \text { uptake } \\
(\mu l / \mathrm{hr} .)\end{array}$} \\
\hline & & & & & $\begin{array}{c}\text { Oxalic } \\
\text { acid }\end{array}$ & $\begin{array}{l}\text { Cate- } \\
\text { chol }\end{array}$ \\
\hline \multirow[t]{4}{*}{1} & H.O-homogenate & 6 & 13 & 419.5 & 2514 & 5447 \\
\hline & Fraction-I (0-33\% acetone-ppt.) & 29 & 6 & 90.5 & 2625 & 543 \\
\hline & Fraction-II (33-50\% acetone-ppt.) & 165 & 70 & 1.7 & 281 & 119 \\
\hline & Fraction-1II (50-71\% acetone-ppt.) & 5 & 136 & 4.0 & 20 & 544 \\
\hline \multirow[t]{3}{*}{2} & Extract from Fraction-I* & & & & & \\
\hline & Fraction-IV (0-33\% acetone-ppt.) & \pm & \pm & 2.1 & \pm & \pm \\
\hline & Fraction.V (50-71\% acetone-ppt.) & 915 & & 0.9 & 835 & \\
\hline \multirow[t]{6}{*}{3} & Sonicate** & & & & & \\
\hline & Fraction-VI $(8,000 \times g$ ppt. $)$ & 24 & & 46.0 & 1004 & \\
\hline & Fraction-VII $(24,0 \mathrm{c} 0 \times g$ ppt. $)$ & 11 & & 38.4 & 4225 & \\
\hline & Fraction-VIII $(24,000 \times g$ super. $)$ & 66 & & 28.0 & 1848 & \\
\hline & $\begin{array}{r}\text { Fraction-1X }(0-50 \% \text { acetone-ppt. } \\
\text { of Fraction-VIII })\end{array}$ & 8 & & 10.2 & 82 & \\
\hline & $\begin{array}{ll}\text { Fraction-X (50-71 } & \text { acetone-ppt. } \\
& \text { of Fraction-VIII })\end{array}$ & \pm & & \pm & \pm & \\
\hline
\end{tabular}

* Extract with $0.01 \mathrm{M}$ phosphate buffer, pH 5.5 .

** Sonic extract was prepared from 1,500 to $8.000 \times g$ fraction of the orginal homogenate. 
Table 8. Effects of varying concentrations of oxalic acid and chloroplasts on oxalic acid oxidase activity.

Reaction condition: $0.02 \mathrm{M}$ phosphate buffer of final concentration, $\mathrm{pH} 5.5$, amounts of potassium oxalate and chloroplast fraction as indicated, $2.0 \mathrm{ml}, 30^{\circ}, 20$ minutes.

\begin{tabular}{|c|c|c|c|}
\hline $\begin{array}{l}\text { Exp. } \\
\text { No. }\end{array}$ & Addition & Concentration & $\mathrm{QO}_{2}$ \\
\hline \multirow[t]{4}{*}{$1 *$} & Oxalate & 0.066 to $0.1 \mathrm{M}$ (final conc) & 28 \\
\hline & & 0.015 to $0.04 \mathrm{M}(" \prime)$ & 20 \\
\hline & & $0.0066 \mathrm{M}$ & 15 \\
\hline & & $0.00066 \mathrm{M}(")$ & 11 \\
\hline \multirow[t]{4}{*}{$2 * *$} & Chloroplasts & $1.5 \mathrm{mg}$ dry weight & 13 \\
\hline & & $1.0 \mathrm{mg}$ dry weight & 10 \\
\hline & & $0.5 \mathrm{mg}$ dry weight & 10 \\
\hline & & $0.25 \mathrm{mg}$ dry weight & 10 \\
\hline
\end{tabular}

* $3.0 \mathrm{mg}$ of dry weight of Sediment-1.

** $0.02 \mathrm{M}$ of final concentration of oxalate.

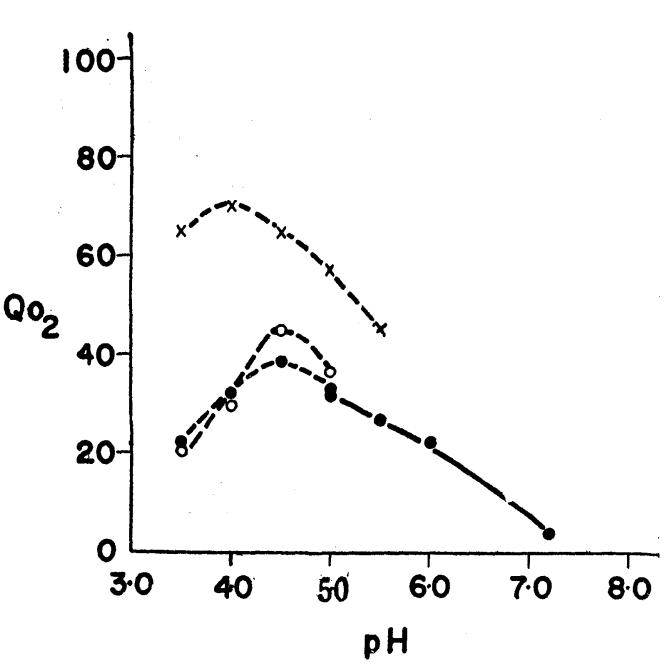

Fig. 1. Effect of $\mathrm{pH}$ on oxidation of oxalic acid by several fractions of leaf homogenate. - curve obtained in phosphate buffer; --.-, curves obtained in acetate buffer; $1,500 \times g$-sediments, $6.2 \mathrm{mg}$ dry weight; $3,000 \times g$-sediments, $3.6 \mathrm{mg}$ dry weight; $\times$, $100 \%$ saturated $\left(\mathrm{NH}_{4}\right)_{2} \mathrm{SO}_{4}$-precipitates, $3.2 \mathrm{mg}$ protein.

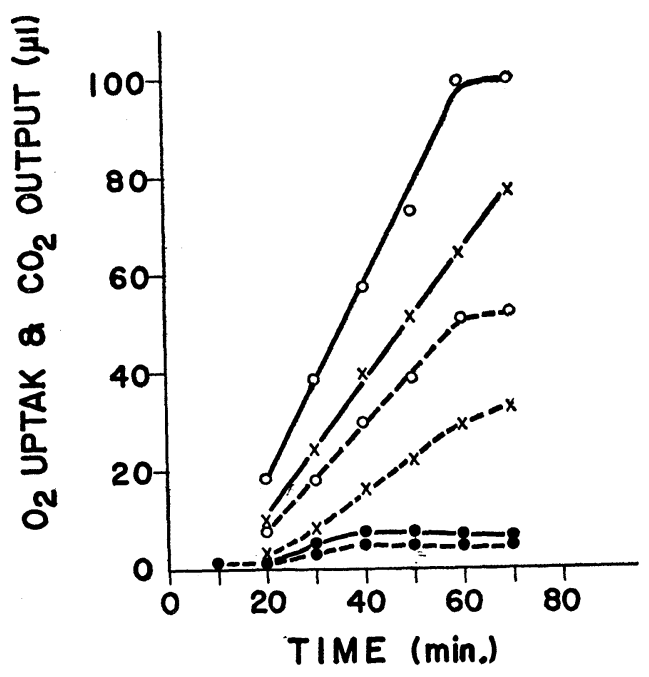

Fig. 2. Effect of FMN on oxidation of oxalic acid by chloroplast fraction. ----, oxygen uptake; - carbon dioxide output; , without oxalate; $\bigcirc$, with oxalate; $x$, with oxalate and FMN.

Effect of DOC and digitonin: Chloroplast fractions were treated with $0.5 \%$ DOC or $1 \%$ digitonin in $0.25 \mathrm{M}$ sucrose solution. Oxalic acid oxidase was more easily extracted with COC than with digitonin or deionized water (Table 5).

Fractionation with $\left(\mathrm{NH}_{4}\right)_{2} \mathrm{SO}_{4}$ : The enzymes were fractionated with $\left(\mathrm{NH}_{4}\right)_{2} \mathrm{SO}_{4}$ from the supernatant separated by centrifugation at $24,000 \times g$ from the waterhomogenate. Most of oxalic acid oxidase was found in the fraction obtained with $10 \%$ saturated $\left(\mathrm{NH}_{4}\right)_{2} \mathrm{SO}_{4}$, while catechol enzyme was largely retained in the fraction 
Table 9. Thermostability of oxalic acid oxidase.

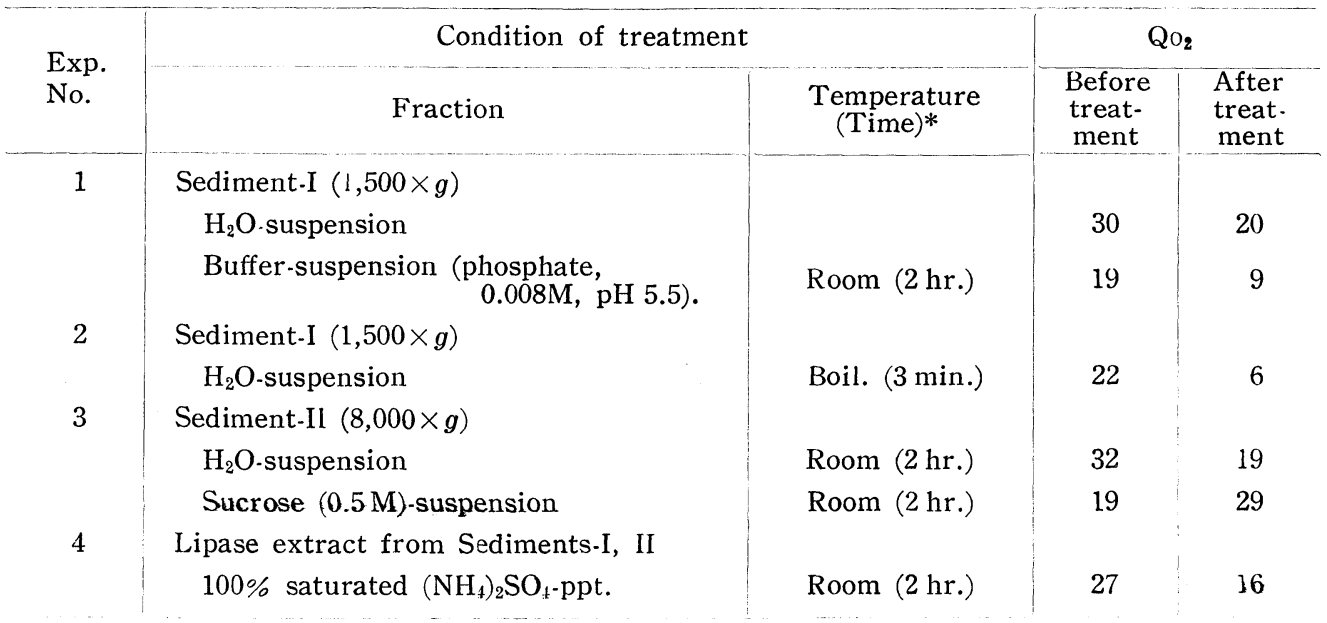

* Room temperature was about $20^{\circ}$.

Table 10. Effects of flavin compounds on activity of oxalic acid oxidase of chloroplast fractions.

Reaction condition: $0.02 \mathrm{M}$ phosphate b fffer, $\mathrm{pH} 5.5 ; 0.02 \mathrm{M}$ potassium oxalate; $5 \mathrm{mg}$ of chloroplast (Sediments at $1,500 \times g$ from $0.5 \mathrm{M}$ sucrose-homogenate), $1 \mu \mathrm{g}$ of flavin compound, $2.0 \mathrm{ml} ; 30^{\circ}, 10$ minutes.

\begin{tabular}{|c|c|c|c|c|c|}
\hline \multirow[b]{2}{*}{$\begin{array}{l}\text { Exp. } \\
\text { No. }\end{array}$} & \multirow[b]{2}{*}{ Addition } & \multicolumn{4}{|c|}{ Activity of oxalic acid oxidase } \\
\hline & & $\begin{array}{l}\mathrm{O}_{2} \text { uptal } \\
\text { without } \\
\text { Oxalate }\end{array}$ & $\begin{array}{l}10 \text { min.) } \\
\text { with } \\
\text { Oxalate }\end{array}$ & $\begin{array}{l}\text { without } \\
\text { Oxalate }\end{array}$ & $\begin{array}{c}\text { with } \\
\text { Oxalate }\end{array}$ \\
\hline \multirow[t]{2}{*}{1} & None & 2 & 22 & 2.7 & 2.4 \\
\hline & FMN & 6 & 39 & 1.0 & 2.3 \\
\hline \multirow[t]{4}{*}{2} & None & 1 & 37 & & \\
\hline & FMN & 1 & 58 & & \\
\hline & FAD & 1 & 12 & & \\
\hline & $\mathrm{RF}$ & 1 & 22 & & \\
\hline
\end{tabular}

obtained with 50 to $100 \%$ saturated $\left(\mathrm{NH}_{4}\right)_{2} \mathrm{SO}_{4}$. The former enzyme was fractionated with $100 \%$ saturated $\left(\mathrm{NH}_{4}\right)_{2} \mathrm{SO}_{4}$ from the lipase-treated extract of chloroplast fraction. In this case, the precipitates were separated into two fractions by centrifugation at $10,000 \times g$ and $13,000 \times g$ from the lipase-treated extract. First sediment was collected by centrifugation at $10,000 \times g$ and second sediment at $13,000 \times g$. Most of oxalic acid oxidase and catechol enzymes were present in the sediment obtained at $10,000 \times g$ (Table 6).

Fractionation with acetone: The major part of oxalic acid oxidase was found in the precipitates obtained with $33 \%$ acetone from the $24,000 \times g$-supernatant with a low activity, while a part of the enzyme was precipitated by $50 \%$ acetone with a 
Table 11. Effects of inhibitors on activity of oxalic acid oxidase.

\begin{tabular}{|c|c|c|}
\hline Inhibitor $(\mathrm{M})$ & Enzyme fraction & $\begin{array}{c}\text { Inhibition } \\
\text { of } \\
\text { oxidation of oxalate }\end{array}$ \\
\hline Acriflavin $\left(2 \times 10^{-3}\right)$ & $\begin{array}{l}50 \% \text { acetone ppt. } \\
71 \% \text { acetone ppt. }\end{array}$ & $\begin{array}{l}17 \% \\
11\end{array}$ \\
\hline Benzoate $\left(10^{-3}\right)$ & $50 \%$ acetone ppt. & 99 \\
\hline Chloropromazin $\left(2 \times 10^{-4}\right)$ & $100 \%$ acetone ppt. & 100 \\
\hline $\begin{aligned} \mathrm{KCN} & \left(2 \times 10^{-3} \mathrm{M}\right) \\
& \left(10^{-2}\right) \\
& \left(10^{-2}\right)\end{aligned}$ & $\begin{array}{l}\text { Sediment-II }(8,000 \times g) \\
\text { Sediment-II }(8,000 \times g) \\
100 \% \text { sat. }\left(\mathrm{NH}_{4}\right)_{2} \mathrm{SO}_{4} \mathrm{ppt} .\end{array}$ & $\begin{array}{l}(160)^{*} \\
(160)^{*} \\
(160)^{*}\end{array}$ \\
\hline $\begin{aligned} \mathrm{NaN}_{3} & \left(2 \times 10^{-3}\right) \\
& \left(10^{-2}\right) \\
& \left(10^{-2}\right) \\
& \left(10^{-2}\right)\end{aligned}$ & $\begin{array}{l}\text { Sediment-II }(8,000 \times g) \\
100 \% \text { sat. }\left(\mathrm{NH}_{4}\right)_{2} \mathrm{SO}_{4} \mathrm{ppt} . \\
50 \% \text { acetone ppt. } \\
71 \% \text { acetone ppt. }\end{array}$ & $\begin{array}{l}84 \\
60 \\
50 \\
50\end{array}$ \\
\hline $\mathrm{NaNO}_{3}\left(10^{-4}\right)$ & Sediment.II $(8.000 \times g)$ & 100 \\
\hline $\mathrm{NaNO}_{2}\left(10^{-2}\right)$ & Sediment-II $(8,000 \times g)$ & 30 \\
\hline$\left(\mathrm{NH}_{4}\right)_{2} \mathrm{SO}_{4}\left(10^{-2}\right)$ & Sediment-II $(8,000 \times g)$ & $(110-130)^{*}$ \\
\hline
\end{tabular}

*\% of stimulation.

high activity (Table 7). The enzyme was extracted with $0.01 \mathrm{M}$ phosphate buffer, $\mathrm{pH} 5.5$, from the $33 \%$-acetone precipitate following a secondary precipitation with 50 to $71 \%$-acetone. On the other hand, most of catechol enzyme was found in the $71 \%$ acetone precipitate with the high grade of specific activity. From the sonic extract of chloroplast fraction, oxalic acid oxidase was precipitated by $50 \%$ acetone.

Optimum pH: Optimum $\mathrm{pH}$ for the oxidation of oxalic acid by various fractions of leaf homogenate was 4.5 , and the value was the same either with acetate or with phosphate buffer (Fig. 1).

Optimum Concentration of Chloroplasts: Under the conditions of the reaction detailed in Table 8 , the rate of oxalic acid oxidation was little affected by varying the concentration of chloroplast in the reaction mixture from 0.25 to $1.5 \mathrm{mg}$.

Stability of enzyme: The activity of oxalic acid oxidase was strongly declined by boiling crude preparation for 3 minutes. The exposure of the preparation to $30^{\circ}$ for 1 hour or to room temperature (about $20^{\circ}$ ) for 2 hour brought about the partial inactivation, except for in the presence of $0.5 \mathrm{M}$ sucrose (Table 9).

Effect of flavins: The addition of FMN to the suspension of washed chloroplast

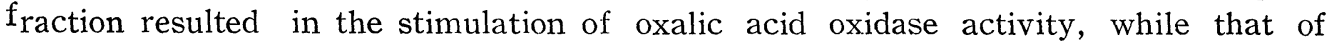
FAD or RF brought about the depression of its activity (Table 10, Fig. 2).

$R Q$ value for oxidation of oxalic acid: The $\mathrm{RQ}$ value of oxidation of oxalate by chloroplast fractioc was approximately 2.4 with or without FMN at pH 5.5. The value for endogenous respiration was 2.3 and was dropped to 1.0 by the addition of FMN (Table 10).

Reactivity with electron acceptors: Methylene blue, 2,6-dichlorophenol indophenol nitrate, or nitrite were not reduced by the chloroplast fraction in the presence of oxalic acid as electron donor under the aerobic and anaerobic conditions.

Effect of inhibitors: $\mathrm{NaN}_{3}\left(2 \times 10^{-3} \mathrm{M}\right)$ partially inhibited the activity of oxalic acid oxidase of chloroplasts and solubilized fractions. The latter fraction appeared to be more resistant to $\mathrm{NaN}_{3}\left(10^{-2} \mathrm{M}\right)$ than the former fraction as regards the oxidation of oxalate. On the contrary $\mathrm{KCN}\left(2 \times 10^{-3}\right.$ and $\left.10^{-2} \mathrm{M}\right)$ stimulated the enzyme activity. Benzoate $\left(10^{-3} \mathrm{M}\right)$ and chloropromazine $\left(2 \times 10^{-2} \mathrm{M}\right)$ suppressed the enzyme activity of 
solubilized enzyme preparation completely, while acriflavin $\left(2 \times 10^{-3} \mathrm{M}\right)$ inhibited only slightly. $\mathrm{NaNO}_{3}\left(10^{-4} \mathrm{M}\right)$ inhibited the enzyme activity completely and $\mathrm{NaNO}_{2}\left(10^{-2} \mathrm{M}\right)$ did not, while $\left(\mathrm{NH}_{4}\right)_{2} \mathrm{SO}_{4}\left(10^{-2} \mathrm{M}\right)$ rather stimulated it (Table 11).

\section{Discussion}

Oxalic acid and oxalic acid oxidase were found to occur in various tissues of Begonia semferflorens. Thus, it was unlikely that oxalic acid metabolism was confined to leaves or chloroplasts.

Laties ${ }^{19)}$ reported that oxalic acid oxidase of chloroplasts from spinach leaves was a cyanide insensitive enzyme and produced both hydrogen peroxide and carbon dioxide. The enzyme from spinach leaves indicated the optimum $\mathrm{pH}$ of 4.5 and $\mathrm{RQ}$ value of 1.4 to 1.5. Arnon and Whatley ${ }^{9)}$ postulated the following reaction routes for the oxidation of oxalic acid in chloroplasts of sugar beet:

$$
\begin{array}{rll}
\text { 1. } & \mathrm{H}_{2} \mathrm{C}_{2} \mathrm{O}_{4}+\mathrm{O}_{2} & -\longrightarrow 2 \mathrm{CO}_{2}+\mathrm{H}_{2} \mathrm{O}_{2} \quad(\mathrm{RQ}=2) \\
\text { 2. } & \mathrm{H}_{2} \mathrm{O}_{2} & -\longrightarrow \mathrm{H}_{2} \mathrm{O}+1 / 2 \mathrm{O}_{2} \\
\text { Sum: 3. } & \mathrm{H}_{2} \mathrm{C}_{2} \mathrm{O}_{4}+1 / 2 \mathrm{O}_{2} & \longrightarrow 2 \mathrm{CO}_{2}+\mathrm{H}_{2} \mathrm{O} \quad(\mathrm{RQ}=4)
\end{array}
$$

Both the consumption of oxygen and the development of carbon dioxide in the presence of oxalic acid and chloroplasts were inhibited strongly by iodoacetamide, 2, 6-dinitrophenol, diethyldithiocarbamate, $\mathrm{NaF}$ and weakly by $\mathrm{NaN}_{3}, \mathrm{NH}_{2} \mathrm{OH}$, and by cyanide. The optimum $\mathrm{pH}$ for this reaction was 5.0. Oxalic acid oxidase from a certain moss was a cyanide insensitive FMN-enzyme ${ }^{5)}$. Also, Finkle and Arnon ${ }^{10)}$ stated that oxalic acid oxidase of chloroplasts of sugar beet was a flavin enzyme, producing hydrogen peroxide. Flavin enzymes, such as glycolic oxidase, are found in many plants widely.

Oxalic acid oxidase of Begonia leaves had several properties resembling that of spinach leaves: optimum $\mathrm{pH}$ of 4.5 , cyanide-insensibility, partial inhibition by $\mathrm{NaN}_{3}$, $\mathrm{RQ}$ value of about 2.0, etc. Then, oxalic acid oxidase of Begonia leaves was probably a FMN-enzyme which produces hydrogen peroxide and carbon dioxide according to the reaction routes postulated by Arnon and Whatley ${ }^{9)}$. The observed partial inhibition by $\mathrm{NaN}_{3}$ may be regarded as the inhibition of catalase followed by accumulation of inhibitory amounts of hydrogen peroxide.

The sensibility of oxalic acid oxidase of Begonia leaves to minimum amounts of nitrate resembles that of moss.

The physiological role of oxalic acid metabolism in plants was not clarified. Arnon and Whatley ${ }^{9}$ assumed that oxalic acid was concerned with the excess accumulation of anions such as $\mathrm{NO}_{3}{ }^{-}$. The possible role of oxalic acid oxidation may be concerned with nitrate respiration in a way of oxidation of oxalic acid coupled with reduction of nitrate, preventing the accumulation of large amount of nitrate in the cells. In the present studies with the chloroplast fractions, the reduction of nitrate or nitrite was not observed in the presence of oxalic acid aerobically and anaerobically. But, the possible role of oxalate in the cells as an electron donor in nitrate respiration or as a carbon source giving carbon dioxide remains to be clarified in further studies.

\section{Summary}

1. Oxalic acid and oxalic acid oxidase were found in various tissues of Begonia semperflorens.

2. Most of oxalic acid oxidase was associated with chloroplast fractions and a part of the enzyme was extracted by the treatment with deoxycholate, digitonin, or 
lipase from the particulate fractions.

3. Oxalic acid oxidase was partially purified by the treatment with 50 to 71 per cent acetone and with saturated ammonium sulfate from the crude extract.

4. Optimum $\mathrm{pH}$ of 4.5 and $\mathrm{RQ}$ value of 2.4 were found for the oxidation of oxalic acid by the chloroplast fractions.

5. Flavin mononucleotide stimulated the oxidation of oxalic acid by the particulate fractions.

6. Activity of oxalic acid oxidase in various enzyme preparations was inhibited strongly by benzoate, chloropromazine and nitrate, and weakly by azide, but not by cyanide.

The author wishes to thank Professor Shoichiro Usami for his invaluable advice and criticism.

\section{References}

1) Smith, V. A., Arch. Biochem. 22: 275 (1949). 2) Hayaishi, O., Shimazono, H., Katagiri, M., and Saito, Y.. J. Am. Chem. Soc. 78: 5126 (1956). 3) Cleland, W. W., and Jonson, M. J., J. Biol. Chem. 220: 595 (1957). 4) Franke, W., Schumann. F., and Benerjee, B., Z. physiol. Chem. 278: 24 (1947). 5) Datta, P. K., and Meeuse, B. J. D., Biochim. Biophys. Acta 17: 602 (1955). 6) Niekerk-Blom. C. J., Proc. Konink1. Nederland. Akad. Wetenschap. 49: 1096 (1949): Ann. Rev. Plant Physiol. 1: 216 (1950). 7) Jakoby, W. B., Ohmura, E., and Hayaishi, O., J. Biol. Chem. 222: 435 (1958). 8) Shimazono, H., and Hayaishi, O., J. Biol. Chem., 227: 151 (1957). 9) Arnon. D. I., and Whatley, F. R., Physiol. Plantarum 7: 602 (1954). 10) Finkle, B. J., and Arnon, D. I., ibid. 7: 614 (1954). 11) Blat, S., and Barker. H. A., J. Bacteriol 55: 359 (1948). 12) Jayasuriya, C. N., J. Gen. Microbiol. 12: 419 (1955). 13) Vishiak, W., Horecker, B. I , and Ochoa, S., Adv. Enzymol. 19: 1 (1957). 14) Quayle, J. R., Fuller, R. C., Benson, A. A., and Calvin, M., J. Am. Chem. Soc. 76: 3610 (1955). 15) Quayle, J. R., and Keech, D. B., Ann. Rev. Microbiol. 13: 69 (1959). 16) Jakoby, W. B., and Blat, J. W., Bacteriol. Revs. 22: 75 (1958). 17) Neilson, N. E., J. Bacteriol. 27: 356 (1956). 18) Mayer, A. M., and Friend, J., J. Exptl. Bot. 11: 141 (1960). 19) Laties, C., Arch. Biochem. Biophys. 27: 404 (1950).

\section{摘要 \\ 佐々木喜美子： ベゴニアにおけるシュウ酸代謝に関する研究}

ベゴニアの種々の器官，特に葉や花异には多量のシュウ酸が含まれている．またシュウ酸は種々の器 官，組織によって酸化的に代謝される。葉に和けるシュウ酸酸化の活性は特に葉緑体区分に強くあらわ れ，その至適 $\mathrm{pH}$ は 4.5, RQ は 2.4 付近の值を示す、.シュウ酸を酸化する酵素は，葉緑体区分からデオキ シコール酸, ジギトニン，あるいはリパーゼ処理などによって部分的に溶出され，たた50〜71\%アセトン あるいは飽和硫酸アンモニウムによって粗酵素液から沈でんせられる。ぬたとの活性はフラビン・モノヌ クレオタイド添加によって促進され，安息香酸塩，クロールプロマジン，抒よび硝酸塩によって強く，あ るいはアザイドによってわずかに阻菁されるが，青酸塩によって阻書されない（北海道大学理学部植物 学室教) 